\title{
Exigencia de altura: un estudio sociológico sobre las preferencias de talla en jóvenes filipinos seleccionados en base a relaciones heterosexuales
}

\section{Tall order: A sociological study on height preferences of selected Filipino youth in heterosexual relationships}

\author{
Richard Jonathan O. Taduran ${ }^{1 \mathrm{a}}$ \\ University of the Philippines Diliman, Quezon City, Philippines ${ }^{1}$ \\ University of the Philippines Mindanao, Davao City, Philippines ${ }^{1}$ \\ D ORCID ID: https://orcid.org/0000-0001-7660-6680¹
}

Recibido: 28 de octubre de2020

Aceptado: 27 de marzo de 2021

\begin{abstract}
Resumen
La altura de una persona se ha convertido en un tema de creciente interés no solo en las ciencias biológicas sino también en las ciencias sociales. La altura de los filipinos rara vez se ha estudiado, y la preferencia de altura en la pareja romántica de filipinos nunca ha sido un tema de investigación. Se recopilaron datos de 100 estudiantes de la Universidad de Filipinas utilizando cuestionarios abiertos de encuestas cualitativas. Los resultados muestran que la mayoría de las mujeres encuestadas (96\%) prefieren salir con hombres más altos que ellas. La explicación de las preferencias de altura basada en el género parece más prominente que la legitimación basada en la evolución.
\end{abstract}

Palabras clave: relaciones románticas, selección de pareja, preferencia de altura, normas sociales, roles de género, juventud, heterosexualidad

\begin{abstract}
The height of a person has become a topic of increasing interest not only in biological sciences but also in the social sciences. Filipino height has rarely been studied, and height preference in romantic coupling of Filipinos has never been a topic of any research. This study aimed to discern the meaning of height in heterosexual romantic relationships of selected Filipino youth: whether height preferences for the opposite sex matter and if so, what those preferences are and the reasons behind such preferences. Data were collected from 100 students of the University of the Philippines by utilizing open-ended qualitative survey questionnaires. Results show that most female respondents (96\%) preferred to date men taller than them. Both females and males believe that height is an important factor in romantic relationships, both citing various reasons such as society, protection, masculinity/femininity, power, and aesthetics. Gender-based explanation of height preferences appear more prominent than evolutionary-based legitimation.
\end{abstract}


Keywords: romantic relationships, mate selection, height preference, social norms, gender roles, youth, heterosexuality.

\section{Introduction}

In every human population, height of males appeared to be greater than females (Mark, 2014; Wall-Scheffler, 2012). Darwin (2019) first theorized that sexual dimorphism could be attributed to sexual selection through male-male competition, for when it comes to competition for access to females in most species; it is usually the larger male that wins.

A few studies on height preferences in mate selection exists and share consistent results: both sexes prefer relationships in which the man is taller and the woman is shorter (Jonasonet al, 2013; Rott, 2010; Sorokowski et al, 2015; Valentova et al, 2014; Stephen and Perera, 2014). Wood and Carden (2014) noted that women are most likely attracted to taller men because of the impression of strength, while Yancey and Emerson (2014) concluded that women prefer to date men who are taller than them due to "protection and femininity" reasons attached to social expectations or gender stereotypes.

When it comes to height perception, studies have shown that tall males are deemed to be more “masculine” (Griffith, 2017), of higher status (Stulpet al., 2013; Phillip, 2014), capable and competent (Thompson, 2014; Re, 2013; Watkins et al, 2010; Winter et al, 2020; Bittman, 2019; Murray and Schmitz, 2011), dominant and assertive (Re et al, 2013;Schmitz and Murray, 2017; Olivola and Todorov, 2010; Valentova et al, 2014), and respected and feared by potential opponents (Lewis et al, 2013). Height in males has also been positively correlated with cognitive abilities (Bittman, 2019; Adonis, 2011; Kobayashiet al, 2018), and social and financial success (Phillip, 2014; Bittman, 2019; Bargain and Zeidan, 2017; Adonis, 2011).

Taller men, therefore, could imply good physical health and longevity (Wang et al, 2017; Kordsmeyer and Penke, 2017; Jarosz and Gugushvili, 2019; Floud et al, 2011), and is positively correlated with reproductive success (Sear, 2010; Conroy-Beam and Buss, 2019; Furnham and McClelland, 2015; Plavcan, 2011; Stulp, et al, 2015). It has been reported that tall males are selected by women in the fertile phase (Wood and Carden, 2014), have more attractive partners (Brewer, 2017), and they do date more often (Skrindaet al, 2014; Buunket al, 2019; Wood and Carden, 2014).

Yet the female preference for taller males may not be universal. For the seminomadic Himba ethnic group of Namibia, Sorokowski, et al (2012) discovered that 34\% of females and $31 \%$ of males preferred couples to be of equal height, and this may be due to the notions associated with lower height, such as poor health, fewer resources during development, and the higher likelihood of producing an offspring that is short in height. 
Although many researches have been conducted on height of different human populations, Filipino height has rarely been reported (Go, 2020), with only one more recent study (Taduran, et al., 2017), yet it was more focused on forensic applications. Height preference in romantic coupling of Filipinos has never been a topic of any published journal article. Meanwhile, height studies in relation with Philippine cultural contexts may have been overlooked, therefore it could be suggested that no existing literature provides academic evaluation of height perceptions in the local context and in current times.

So, this study aimed to examine the significance of height in heterosexual romantic relationships of the Filipino youth, to discover whether they have height preferences for the opposite sex and if so, what those preferences are and why they subscribe to such preferences, respectively. This research also sought to explore the experientiality of height pertaining to the youth's gender-based preferences and the gleanings in their narrations of individual testimonies regarding their height in romantic relationships.

\section{Methodology}

A qualitative survey with open-ended questions was conducted on 100 student volunteers from the University of the Philippines (50 males and 50 females), aged 18 to 22 years old. Topics discussed were related with Filipino youths' perception regarding height in romantic relationships. Questions ranged from what they believe is the right height in men and women to who should be taller in a heterosexual relationship. They were also asked to explain the reasons behind their answers, which were categorized into two: gender roles/social norm and evolutionary biology. The data collected were then arranged into a comprehensive matrix and thematic coding of responses was employed to reduce qualitative data into typologies. Deep saturation technique was conducted to validate the data collected. Responses became more consistent across the subjects, so the data became more reliable.

Four major themes emerged, in concordance with Yancey and Emerson’s (2014) results: Society, Protection, Masculinity/Femininity and Power. Society pertains to the respondents' concepts on the social norms on height. Protection refers to the respondents about their predisposition for protection in a relationship and how this is linked to height. Masculinity/Femininity refers to the respondents discussing their desire for the opposite sex to be within a certain height range and its relation to masculine and feminine notions. Power, meanwhile, pertains to the respondents and their ascription of height to who in the relationship possesses the most power. One theme, Aesthetics, curiously arose and seemed to be important among the respondents. Aesthetics refers to the respondents on the aesthetic appeal of height in relationships. This could be a culture-specific theme for Filipinos when it comes to height preferences. 
All participants in this research were undergraduate students from the University of the Philippines at Diliman, Quezon City, Philippines. This study was limited by this population bias, although the results can still be useful in height studies in anthropology and the behavioral sciences. Names of all respondents are withheld to protect their identities.

Informed consent was obtained from all individual participants included in the study. All methods performed in this study were in accordance with the ethical standards of the institutional and/or national research committee, and with the 1964 Helsinki declaration and its later amendments or comparable ethical standards.

\section{Results}

The preference for a taller male in a heterosexual relationship emerged when respondents were asked who should be taller in a couple. Of the male respondents, $76 \%$ said that men should be taller. Most female respondents (96\%) preferred a taller man in a couple. Fifty four percent (54\%) of male and $66 \%$ of female respondents supported their answer by citing it is the social norm. Thirty percent (30\%) of male and $42 \%$ of female participants specifically said that a taller man shows he can protect his woman. The same value of $42 \%$ in male and female respondents reasoned that a taller man shows he is more superior, stronger, and more dominant in a relationship. Some $50 \%$ of males and $60 \%$ of females discussed in terms of aesthetics - because a couple with a taller man and shorter woman is more pleasing to the eyes.

\section{Table 1}

Percentage of preference and reasons for taller male heterosexual relationships of filipino youth

\begin{tabular}{lcc}
\hline Male & Preference for taller male heterosexual relationships & Female \\
\cline { 1 - 1 } & & $96 \%$ \\
& & \\
$54 \%$ & Reasons & \\
$30 \%$ & Social Norm & $66 \%$ \\
$42 \%$ & Protection & $42 \%$ \\
$50 \%$ & Superiority & $42 \%$ \\
\hline
\end{tabular}

Female respondent \#9 explained why men should be taller than women and they should never be of the same height: “Men should be taller than women. A man's height indicates his capability to protect a woman from harm. Height also intimidates other men who may have wicked intentions, such as rapists and stalkers. If they see a woman with a tall man, they would feel intimidated. I do not agree that men and women should be of the same height because the purpose to intimidate would be lost, as well as the assurance for the woman that she is secured and protected.” 
Female respondent \#30 echoed the same sentiment and cited biology as one of the reasons behind it: "I think this has something to do with biology that women prefer taller men more because it shows they are able to protect the woman. It also shows dominance and perhaps strength as well."

Interestingly, female respondent \#14 said the man should be taller, but not too much: just enough to "possess the appearance” of being dominant. "Not much though but enough that he possesses the appearance of being the 'dominant' of the relationship (even though in some cases, emotionally the female is). I think it is an ingrained preference but a taller person simply shows that they are more able-bodied to provide and protect the 'submissive' of the relationship. In other cases, however, it's fine if they're the same height simply because height doesn't really define much of a relationship.”

Female respondent \#8 noted how height adds to the man's masculinity and a taller woman would signify her partner is beneath or under her. "First of all, height adds to their masculinity, men look more assertive, manlier. On another note, if the woman is taller, it looks intimidating. It looks as if her partner is under her skirt.”

Meanwhile, male respondent \#3 stated the man should be taller, otherwise he may feel some sort of inferiority: "The man must be taller than the woman. This is so men would not feel any inferiority.” Male respondent \#29 also mentioned patriarchy as the reason behind why women want a taller partner to feel protected: “The society we move in is patriarchal. Many women want to be shorter than men because for them, they are more protected if the man is taller."

Some respondents explained their preference for a taller man in a relationship by saying it is the model, it is what is commonly seen, so it is also more pleasing to the eyes. Aside from strength and power, an aesthetic side to this preference emerged, one that appeals to the senses. Male respondent \#45 shared men should be taller than women because if it were the opposite, the couple would not look so pleasing. "In Philippine society and culture, it looks more pleasant when the man is taller than his partner. It is okay if they are the same height, but it looks inappropriate if the woman is taller.”

Male respondent \#12 supposed that women who are too tall are not attractive. He reasoned: "It just doesn't look appealing in a couple when a woman is too tall." Female respondent \#50, meanwhile, said that although it may be okay if the couple were the same height, it still looks more aesthetically appealing if the man was taller. "I suppose it would work if the couple were the same height, but it looks more pleasant if the man was taller. In my opinion, the couple is more aesthetically appealing if it was like that. As a woman, it feels good to be able to wrap my arms around the man’s shoulders and neck when he is taller.”

Female respondent \#29 also said that ideally, the man should be taller. It looks more normal, especially if a couple are "holding hands while walking." "Ideally, it should be the man 
who is taller, but nowadays, it seems it is no longer applicable. They say if you love someone then you love them regardless of any flaw. But then again, it's more 'normal' to see if the man is taller, especially when they're HHWW (holding hands while walking).”

Does a taller height indicate attractiveness? For $24 \%$ of male and $36 \%$ of female respondents, they believe that tall males are indeed good looking. Male respondent \#33 expressed: "It is easier to have a partner if you are tall because you stand out.” Male respondent \#18 said tall men appear to be handsome even if they are not so: “A tall man is usually admired by people and becomes handsome even if they are not really so.” Female respondent \#41 said, "I believe that more women would be attracted to a tall man." Female respondent \#1 echoed the same sentiment and shared a tall friend of hers said the greatest advantage of being a tall man is that many girls approach him: "I have a male friend who we call 'six-six' because of his height. He said it himself that the greatest advantage of being tall is that women love it and many approaches him because of it.”

Meanwhile, some $38 \%$ of male $24 \%$ of female participants perceived short females to be more attractive and desirable. Female respondent \#23 said: "Yes, according to my [male] friends, short girls are cuter and they are more attracted to them.” Female respondent \#27 said a short woman has more prospects for a potential boyfriend: "If you are a short woman, you have more prospects when it comes to a potential boyfriend because you don't think about being awkward should you end up being taller than him.”

Female respondent \#45, who considered herself short, agreed, "It is easier for those courting me to satisfy the height requirement.” Male respondent \#36, on the other hand, said petite women are "cute" and that it is better if women, in general, are short instead of being too tall: "Petite women are cute too, but that depends on one's taste. But for women, personally, it is better if they are short instead of being too tall.”

\section{Discussion}

Majority of the respondents agreed on taller man-shorter woman configuration in romantic relationships. However, gender differences in the importance of height in heterosexual relationships emerged, with most females preferring a taller man in a couple. Yancey and Emerson (2014) noted that the height of a potential partner does matter more to women than men and that "gender-based legitimation" seem to be more central than "evolutionary-based legitimation” when it came to height preferences. Gender-based legitimation refers to the gender role stereotype explanation in height studies that show tallness in males is an indication of power and dominance, thus women have the tendency to prefer tall males for protection and gene selection (Duguid and Goncalo, 2011). They are also perceived to be of higher status (Stulp et al, 2013; Phillip, 2014). 
Five themes emerged from the study, four of which were in concordance with Yancey and Emerson's (2014) results, and they were: Society, Protection, Masculinity/Femininity and Power. Aesthetics curiously arose and seemed to be important among the respondents; this could be a culture-specific theme for Filipinos when it comes to height preferences.

Majority of the respondents mentioned social norm as the explanation behind their preference for a taller man in a heterosexual relationship. For the respondents, Filipino society dictates that men be taller than women as what is commonly seen from most couples. Following this norm, a woman's ideal height of a man most of the time is a height higher than her own. Moreover, more female respondents explained their preference for taller men as an indication of a man's capability to protect the woman.

There is sexual dimorphism in human height and males are typically taller than females. However, in some cases the perception that male height is an indication of his capacity to protect women is considered as a social construct that feeds and enables stereotypical notions of male dominance and female submissiveness. Then, this female preference enables inequality between the sexes by showing the dominance of a man over his submissive woman. It also sheds light on their sexual roles: that the woman has been assigned tasks that do not require strength and physical largeness which the man, on the other hand, need for his laborious tasks as a protector and provider of the family (Afanasieva, et al., 2020). This was noted by Aguja (2013) who said male sexual roles are associated with notions of masculinity such as dominance and assertiveness: while the ideal Filipino wife's responsibility is to keep house and keep her marriage together through patience, hard work, virtue and submission, the husband is obligated to protect his wife and family and be the household's breadwinner.

Yancey and Emerson (2014) have mentioned that the biological advantage of taller men, the capacity to physically protect women from harm, is apparent in its connection "to masculine images of dominance and protector.” Perhaps height had legitimated biological advantages in pre-industrial societies, but the advent of technology may have offset such advantages. As one such respondent mentioned in this study, a man should be "tall enough" that he "possesses the appearance” of being dominant, to show he can protect the woman from those who have wicked intentions. Perhaps in contemporary times, this seeming biological advantage, as far as “protecting” goes, merely serves as a stereotypical front or facade of intimidation.

The social norm that instructs men should be taller than women perpetuates gender stereotypes, which in turn supports and somehow describes a patriarchal society. These stereotypical perceptions manifest in what may seem to be overlooked aspects of the everyday, such as height preferences in romantic relationships, yet insidiously enforce sexual inequality. This was noted by Ocay (2019) who posited that gender norms that constitute the construction of tall men as masculine may be reflected in stereotypical height preferences. While the results in this study are not meant to arrive at sweeping generalizations about Filipinos and Filipino 

youth, especially considering the qualitative nature of the research, it offers further insight into how height preference often demonstrates social and gender stereotypes that dictate men to be taller and women to be shorter in the Philippines.

Yancey and Emerson (2014) also suggested that religious women may more likely have the desire for, and seek taller men who they can "look up to," literally and metaphorically, as compared to secular women. This could be due to the teachings about male headship which may make religious women more susceptible to search for men who are capable of leading or guiding them. The Philippines is a predominantly Catholic country and has a long history of oppression, having been colonized by Spain, the United States of America, and Japan, all of which imposed full authority over social dynamics (Elizalde, 2019; Balay-as, 2019; Ocay, 2019).

It is also known that the Church puts a primacy on male leadership, the separation of the sexes made palpable in the restriction of "pastoral and government functions of the Christian community to men” (Hanafy et al, 2014). While this study did not consider the religious affiliation of the respondents, it could have played a role in the respondents' inclinations and leaves room for future studies on height preferences and perception.

Meanwhile, the question of who in the relationship has more power also rears itself when the respondents were asked about who should be taller in a couple. Height does not exist in a vacuum and cannot be divorced from considerations of gender as well as power relations. If a taller height indicates desire and dominance in men, and dominance indicates power, then it may be gleaned that being dominant and holding the power in a relationship is a positive trait. Some of the male respondents used interesting terms when they explained why men should be taller than women in a relationship and even cited pride and superiority. It seems like for the majority of respondents, however, a taller woman lowers the pride of the man and makes him feel inferior, which is why the man should be the taller one in a relationship.

Majority of the respondents also explained their preference for a taller man in a relationship by saying it is the norm, it is what is commonly seen; therefore, it is what is aesthetically appealing to the eyes. In short, what is normal could also be beautiful. It is interesting to observe that aside from strength and power, there is an aesthetic side to this preference that appeals to the senses. Interesting, still, are the possible reasons as to why the Filipino respondents are so concerned about the aesthetics in this regard. The aesthetic appeal of a man being taller in a relationship is borne out of the social norm that dictates men should be taller and women should be shorter. This is the status quo as commonly seen among most couples; therefore, it has become the standard for what should be "normal" and, perhaps for Filipinos, also what is "beautiful” or "pleasing."

A taller man and shorter woman couple is pleasing to the eyes, but a shorter man and taller woman couple may not be so because it deviates from the norm. Deviating from or 
to a sense of wrongness, and beautiful to ugly, which may explain why the image of a shorter man and a taller woman couple were described as "inappropriate" and "unappealing” to the eye by the respondents.

Still, why were the respondents concerned about aesthetics, in following the standard dictated by the norm? Elster (2013) said that norms are maintained by feelings of embarrassment, angst, guilt and shame, and for norms to be social, they must be of two things: shared by others and partly sustained by other people’s approval and disapproval. Social norms have a "grip on the mind" and feelings of embarrassment and shame are suffered by a person who violates or deviates from these norms, violations that carry strong, negative emotions. This could be the reason why our Filipino participants adhere to norms: to avoid disapproval from other people.

\section{Conclusions}

Height is just one of the varied aspects individuals take into account when it comes to their romantic preferences for the opposite sex and it arguably may or may not be classified as mundane. However, it may not hurt, perhaps, to regard how seemingly prosaic preferences such as height can continue to discriminate and establish social constructs and biases both unconscious and otherwise, and consider how such preferences persist in calcifying gender inequality and the patriarchy, which hurts both men and women.

This study has shown that height indeed plays a factor when it comes to the respondents' considerations of what constitutes as girlfriend or boyfriend material, one of the characteristics they deem important insofar as choosing their romantic partners is concerned. With these things considered, short men and tall women are thus placed at a disadvantage as they are inescapably faulted and, at the same time, pressured to fit a certain standard wherein the defining variable is beyond their control - their height. This seems to leave the average or common Filipino with quite a tall order, so to speak, and perhaps a futile reaching toward a standard that is out of reach.

\section{References}

Adonis, D.L. (2011). The community development concepts of the Igorot indigenous peoples in Benguet, Philippines. DOI:10.4226/66/5a961d63c6866

Afanasieva, L., Bukrieieva, I., Glyns'ka, L., Hlebova, N., \& Semikin, M. (2020). Family Roles of Roma and Ways to Overcome its Socio-Cultural Isolation. Journal of History Culture and Art Research, 9(3), 288-296. http://dx.doi.org/10.7596/taksad.v9i3.2716

Aguja, H.J. (2013). The Filipino Woman: A Gendered History. Corpus ID: 151373387

Balay-as, M. (2019). Disasters through an Indigenous Lens in the Philippines. Corpus ID: 149908466 
Bargain, O., \& Zeidan, J. (2017). Stature, Skills and Adult Life Outcomes: Evidence from Indonesia. The Journal of Development Studies, 53, 873-890. DOI:10.1080/00220388.2016.1208173

Bittmann, F. (2019). The relationship between height and leadership: Evidence from across Europe. Economics and human biology, 36, 100829. DOI:10.1016/j.ehb.2019.100829

Brewer (2017). Height, Relationship Satisfaction , Jealousy , and Mate. Corpus ID: 202607508

Buunk, A.P., Fernández, A.M., \& Muñoz-Reyes, J.A. (2019). Height as Related to SelfPerceived Mate Value and Attractiveness. Evolutionary Behavioral Sciences, 13, 93100. DOI:10.1037/ebs0000132

Conroy-Beam, D., \& Buss, D. (2019). Why Is Age So Important in Human Mating? Evolved Age Preferences and Their Influences on Multiple Mating Behaviors. Evolutionary Behavioral Sciences, 13, 127-157. DOI:10.1037/ebs0000127

Darwin, C. (2019). The Descent of Man. La Vergne: Neeland Media LLC.

Duguid, M. M. \& Goncalo, J. A. (2011). Living large: The powerful overestimate their own height. Retrieved from http://digitalcommons.ilr.cornell.edu/articles/456/

Elizalde, M.D. (2019). Beyond Racial Divisions: Bridges and Intersections in the Spanish Colonial Philippines. Philippine Studies, 67, 343-374. DOI:10.1353/phs.2019.0020

Elster, J. (2013). The Cement of Society: A Study of Social Order. Cambridge: Cambridge University Press.

Floud, R., Fogel, R., Harris, B. \& Hong, S.C. (2011). The changing body: health, nutrition, and human development in the Western world since 1700. New York: Cambridge University Press.

Fonseca, X., Lukosch, S., \& Brazier, F. (2018). Social cohesion revisited: A new definition and how to characterize it. Innovation: The European Journal of Social Science Research, 32(2), 231-253. https://doi.org/10.1080/13511610.2018.1497480

Furnham, A., \& McClelland, A. (2015). What Women Want in a Man: The Role of Age, Social Class, Ethnicity, and Height. Psychology, 06, 278-290. DOI:10.4236/PSYCH.2015.63028

Go, M.C. (2020). Sex and ancestry estimation methods in modern Filipino crania. Dissertation. Chicago: University of Illinois. Retrieved from: https://www.ideals.illinois.edu/bitstream/handle/2142/107918/GO-DISSERTATION2020.pdf? sequence $=1 \&$ isAllowed $=\mathrm{y}$

Griffiths, S., Murray, S., Medeiros, A., \& Blashill, A. (2017). The tall and the short of it: An investigation of height ideals, height preferences, height dissatisfaction, heightism, and height-related quality of life impairment among sexual minority men. Body image, 23, 146-154. DOI:10.1016/j.bodyim.2017.10.001

Hanafy, I.A., Home, I.A., Guin, U.K., \& Kesh, O. (2014). Ecofeminism across Cultures in Le Guin’s Always Coming Home. Corpus ID: 198922514.

Jarosz, E., \& Gugushvili, A. (2019). Parental education, health literacy and children's adult body height. Journal of biosocial science, 1-23. DOI:10.1017/S0021932019000737 
Jonason, P., Webster, G., Gesselman, A.N. (2013). The Structure and Content of Long-Term and Short-Term Mate Preferences. Interpersona: an international journal on personal relationships, 7, 167-179. DOI:10.5964/IJPR.V7I2.125

Kobayashi, L., Berkman, L., Wagner, R., Kahn, K., Tollman, S., \& Subramanian, S.V. (2018). Education modifies the relationship between height and cognitive function in a crosssectional population-based study of older adults in Rural South Africa. European Journal of Epidemiology, 34, 131-139. DOI:10.1007/s10654-018-0453-1

Kordsmeyer, T.L., \& Penke, L. (2017). The association of three indicators of developmental instability with mating success in humans. Evolution and Human Behavior, 38, 704713. DOI:10.1016/J.EVOLHUMBEHAV.2017.08.002

Lasquety-Reyes, J.A. (2016). In Defense of Hiya as a Filipino Virtue. Asian Philosophy, 26, 66-78. DOI:10.1080/09552367.2015.1136203

Lewis, M., Nosek, B.A., Lai, C.K., Ebersole, C.R., Hussey, I., \& Axt, J.R. (2013). Short PeopleTall People IAT. Corpus ID: 188709856

Mark, Q. (2014). Global variance in female population height: the influence of education, income, human development, life expectancy, mortality and gender inequality in 96 nations. Journal of biosocial science, 46(1), 107-21. DOI:10.1017/S0021932013000175

Marshall, A. (2018). Bayanihan and Belonging: Filipinos and Religion in Canada. DOI:10.3138/9781487517519

Martinez, R.C.K. (2019). "Hulas at Hiya": Reflections on Filipino Context of HumanConnectedness and the Nature of Nursing. Journal of Health and Caring Sciences, 1(2), 118-123. https://doi.org/10.37719/jhcs.2019.v1i2.rna004

Murray, G.R. \& Schmitz, J.D. (2011). Caveman politics: evolutionary leadership preferences and physical stature. Social Science Quarterly, 92(5), 1215-1235. https://doi.org/10.1111/j.1540-6237.2011.00815.x

Ocay, J.V. (2019). The Peasant Movement and Great Refusal in the Philippines: Situating Critical Theory at the Margins. Kritike: An Online Journal of Philosophy, 12, 43-67. DOI:10.25138/12.3A3

Olivola, C.Y., \& Todorov, A. (2010). Elected in 100 milliseconds: Appearance-Based Trait Inferences and Voting. Journal of Nonverbal Behavior, 34, 83-110. DOI:10.1007/S10919-009-0082-1

Phillip, A. (2014). Sorry shorties, tall dudes have their pick of the dating pool. Washington Post. Retrieved from: https://www.washingtonpost.com/news/to-yourhealth/wp/2014/08/27/tall-men-have-their-pick-of-the-dating-pool/

Plavcan, J.M. (2011). Understanding dimorphism as a function of changes in male and female traits. Evolutionary Anthropology: Issues, 20. DOI:10.1002/evan.20315

Re, D. (2013). The role of facial cues to body size on attractiveness and perceived leadership ability. Corpus ID: 142714385

Re, D., Hunter, D.W., Coetzee, V., Tiddeman, B., Xiao, D., DeBruine, L., Jones, B., \& Perrett, D. (2013). Looking Like a Leader-Facial Shape Predicts Perceived Height and Leadership Ability. PLoS ONE, 8. DOI:10.1371/journal.pone.0080957 
Rott, L.M. (2010). Why does growth hurt? The dual role of normalization and stigmatization in the experience of growth hormone treatment. DOI:10.1108/S14793547(2010)0000005013

Schmitz, J., \& Murray, G.R. (2017). Perceptions of political leaders. Politics \& Life Sciences, 36, 60 - 79. DOI:10.1017/pls.2017.22

Sear, R. (2010). Height and Reproductive Success. Human Nature, 17, 127-143. DOI:10.1007/978-3-642-12142-5_10

Skrinda, I., Krama, T., Kecko, S., Moore, F., Kaasik, A., Meija, L., Lietuvietis, V., Rantala, M.J., \& Krams, I. (2014). Body height, immunity, facial and vocal attractiveness in young men. Naturwissenschaften, 101, 1017-1025. DOI:10.1007/s00114-014-1241-8

Sorokowski, P., Sorokowska, A., Butovskaya, M., Stulp, G., Huanca, T., \& Fink, B. (2015). Body Height Preferences and Actual Dimorphism in Stature between Partners in Two Non-Western Societies (Hadza and Tsimane'). Evolutionary Psychology, 13. DOI:10.1177/147470491501300209

Sorokowski, P., Sorokowska, A., Fink, B., \& Mberira, M. (2012). Variable preferences for sexual dimorphism in stature (SDS) might not be universal: Data from a semi-nomad population (Himba) in Namibia. Journal of Cross-Cultural Psychology, 43, 32-37. https://doi.org/10.1177/0022022110395140

Stephen, I.D., \& Perera, A. (2014). Judging the differences between women's attractiveness and health: is there really a difference between judgments made by men and women? Body image, 11(2), 183-6. DOI:10.1016/j.bodyim.2013.11.007

Stulp, G., Barrett, L., Tropf, F., \& Mills, M. (2015). Does natural selection favour taller stature among the tallest people on earth? Proceedings of the Royal Society B: Biological Sciences, 282(1806), 20150211-20150211. https://doi.org/10.1098/rspb.2015.0211

Stulp, G., Buunk, A., Verhulst, S., \& Pollet, T. (2013). Tall claims?: Sense and nonsense about the importance of height of US presidents. Leadership Quarterly, 24, 159-171. DOI:10.1016/J.LEAQUA.2012.09.002

Stulp, G., Pollet, T., Verhulst, S., \& Buunk, A.P. (2011). A curvilinear effect of height on reproductive success in human males. Behavioral Ecology and Sociobiology, 66, 375384. DOI:10.1007/s00265-011-1283-2

Taduran, R.J., Tan, M.L., \& Townsend, G. (2017). Different methods for estimating height in a Filipino sample: forensic implications. Australian Journal of Forensic Sciences, 49, 59 - 68. https://doi.org/10.1080/00450618.2015.1122081

Thompson, C.S. (2014). Body Image in Mauritania: Bigger is better. Corpus ID: 128716575

Valentova, J., Stulp, G., Třebický, V., \& Havlíček, J. (2014). Preferred and Actual Relative Height among Homosexual Male Partners Vary with Preferred Dominance and Sex Role. PLOS ONE, 9. DOI:10.1371/journal.pone.0086534

Wall-Scheffler, C. (2012). Energetics, Locomotion, and Female Reproduction: Implications for Human Evolution. Annual Review of Anthropology, 41, 71-85. DOI:10.1146/ANNUREV-ANTHRO-092611-145739

Wang, F., Xu, X., Yang, J., Min, L., Liang, S., \& Chen, Y. (2017). Height and lung cancer risk: A meta-analysis of observational studies. PLoS ONE, 12. DOI:10.1371/journal.pone.0185316 
Watkins, C.D., Fraccaro, P.J., Smith, F.G., Vukovic, J., Feinberg, D., DeBruine, L., \& Jones, B. (2010). Taller men are less sensitive to cues of dominance in other men. Behavioral Ecology, 21, 943-947. DOI:10.1093/BEHECO/ARQ091

Winter, B., Duffy, S.E., \& Littlemore, J. (2020). Power, Gender, and Individual Differences in Spatial Metaphor: The Role of Perceptual Stereotypes and Language Statistics. Metaphor and Symbol, 35, 188 - 205. DOI:10.1080/10926488.2020.1794319

Wood, W., \& Carden, L. (2014). Elusiveness of menstrual cycle effects on mate preferences: comment on Gildersleeve, Haselton, and Fales. Psychological bulletin, 140(5), 126571. DOI:10.1037/a0036722

Yancey, G. \& Emerson, M. (2014). Does height matter? An examination of height preferences in romantic coupling. Journal of Family Issues, 35(4), 526-546. https://doi.org/10.1177/0192513X13519256 